\title{
EGEDY TAMÁS: VÁROSREHABILITÁCIÓ ÉS TÁRSADALOM
}

(MTA Földrajztudományi Kutatóintézet, Budapest, 2005, 305 o.)

\section{VÁRADI ZSUZSANNA}

A mai kelet-közép-európai városok egyik időszerü problémája, az épített környezet folyamatos amortizációja, egyes városrészek - különösen a belvárosi területek, valamint lakótelepek - fizikai társadalmi leromlása. Ezért sürgető igényként merül fel a városok megújítása. A nyugat-európai országokban a városrehabilitációval kapcsolatos elképzelések, a beavatkozás különbözỏ modelljei és a gyakorlati eredmények már több évtizedes múltra tekintenek vissza. S bár a volt szocialista államokban, közte Magyarországon is vannak korábbi városrehabilitációs eredmények, az igazi áttörést az elmúlt évtized második fele adta, a gazdasági stabilitás növekedése, a finanszírozási rendszer, az intézményi háttér erősödése következtében a korábbiakhoz képet markánsabbá váltak a városfelújitási törekvések.

A tudományos eredmények sok szempontból szolgálhatják a városfelújítási törekvések megalapozását, és ezért is fontosak a városrehabilitációval kapcsolatosan megjelent nemzetközi és publikációk. Ezek között igen jelentős egy olyan új szakirodalom, amely átfogó módon elemzi, rendszerezi és gyakorlati példákkal is szemlélteti a témával kapcsolatos ismereteket. Az MTA Földrajztudományi Kutatóintézet tudományos fómunkatársa, Egedy Tamás szerkesztésében megjelent Városrehabilitáció és társadalom címú tanulmánykötet alapjaiban foglalja össze a városrehabilitációhoz kapcsolódó tudnivalókat, gyakorlatorientált megközelítésben.

A 305 oldalas munka jól strukturált, az olvasó logikusan követheti a téma és az ehhez kapcsolódó ismeretanyagok bemutatását. A könyv egyik erénye, hogy több tudomány- és szakterületet (városszociológia, településtudomány, urbanisztika) képviselő kutató és városfejlesztéssel foglalkozó szakember munkájának segítségével, több aspektusból mutatja be a városrehabilitációval kapcsolatos aktuális ismereteket, a témát érintő legfontosabb kutatási eredményeket.

A tanulmánykötetben a fejezetek és tanulmányok logikusan követik a témakör egyre szủkebb területi és logikai megközelítését. Az Olvasó így az elméleti ismeretek megszerzése során fokozatosan ismerkedik meg a városrehabilitáció megjelenési formáival, gyakorlati jelentőségével, konkrét nemzetközi és hazai tapasztalataival.

A kötet első nagy fejezete a „Városrehabilitáció elméletben és gyakorlatban” címet viseli, amely két tanulmányban foglalja össze a városrehabilitáció elméleti kérdéseit. Egedy Tamás és Kovács Zoltán szerzőpáros munkája a városrehabilitáció elméleti megközelítéséhez kíván hozzájárulni, amely során több kérdés felvetésével, fogalmak és modellek magyarázatával, a városrehabilitáció történeti fejlődésével, valamint az új várospolitikai gondolkodásban megjelenő és a gyakorlati megvalósí- 
táshoz szükséges stratégiai, átfogó jellegủ megközelítés fontosságával, az együttmüködési és finanszírozási lehetóségek bemutatásával ismerkedhet meg az Olvasó.

A fejezet második, a Szerkesztő által készített tanulmány „Sikeres városrehabilitáció" címmel, bỏ terjedelemben, 40 oldalban foglalja össze egy nemzetközi kutatási projekt (NEHOM - Neighbourhood Housing Models) vizsgálati eredményeit, a városfelújítási tevékenység legfontosabb gyakorlati tapasztalatait. A NEHOM kutatási projekt 8 európai ország (Egyesült Királyság, Észtország, Franciaország, Magyarország, Németország, Norvégia, Olaszország és Svédország) 11 városában, 26 rehabilitációs területen végzett vizsgálatain alapul, amelynek célja ,olyan innovativ és hatékony városrehabilitációs kezdeményezések feltárása volt, amelyek segítségével a hanyatló városnegyedekben élö lakosság életkörülményei javíthatók”. A kutatás eredményeinek bemutatására több idegen nyelvü kiadvány készült, amelyekben a kutatási projekt eredményeit részletesen ismertetik, jelen tanulmány a vizsgált mintaterületek gyakorlati tapasztalatait, a városfelújítás szempontjából a legfontosabb lépéseket összegzi, valamint javaslatokat tesz a városfelújítással foglalkozó szakemberek és döntéshozók számára. A tanulmány mellékletében a lakónegyedek leggyakoribb problémáival és megoldásukra tervezett akciókkal ismerkedhetủnk meg. Az írás a vizsgálati eredményeket különböző témakörök szerinti csoportosításban tárgyalja, amelyek a városrehabilitáció egymást követő lépéseit tartja szem elött, így a logikus sorrendet követve megismerkedhetünk a felújítási folyamatok tervezésével, a megvalósításához szükséges „rehabilitációs teamek” kialakításával és munkájuk jelentőségével, a kitúzött célok megvalósításának lehetőségével és folyamatával, a lakossági részvétel szerepével, valamint a potenciális források feltárásával és annak mobilizálásával. A tanulmány a témakörök kifejtése mellett javaslatokat tesz arra, hogy a városrehabilitációs tevékenységek milyen módszerek segítségével müködhetnek jobban.

A kötet következö, a „Városfelújítás nemzetközi sajátosságai” címủ fejezetében két tanulmány olvasható, amelyben elsőként a városfejlesztésben kőzremüködő gyakorlati szakember, Soóki-Tóth Gábor mutatja be a Európai Unió városrehabilitációs politikáját, a legfontosabb programokat, valamint a finanszírozással kapcsolatos kérdéseket. A tanulmányban tơrténeti áttekintést ad a szerző az EU városfelújítási tevékenységeihez kapcsolódó kezdeményezésekről (URBAN), a támogatható területek kritériumrendszeréröl, valamint ezek pénzügyi hátteréröl.

A városrehabilitáció nemzetközi tapasztalatainak bemutatásánál a kơvetkező tanulmány a NEHOM projekt egyik összefoglaló kiadványának felhasználásával készült, Egedy Tamás, Kovács Zoltán és Nicola Morrison munkája során. A tanulmány - annak ellenére, hogy témája szorosan összefügg a „Sikeres városrehabilitáció" címủ írással - eltérő módon, elsőként az elméleti háttér bemutatásával, majd a kutatásba bevont rehabilitációs kezdeményezések tapasztalataival, a vizsgált területek összehasonlításával, valamint a projektek más országokban történö átvételének és feltételeinek lehetőségeivel foglalkozik. A tanulmány egyik legfontosabb eredménye az, hogy a vizsgált területek összehasonlításai alapján - a területi sajátosságok meghatározásai után - kiemeli azokat a tényezỏket, szereplőket és 
feladatokat, amelyek a városregeneráció sikeres kialakításához nélkülözhetetlenek, továbbá feltárja azokat a javaslatokat, amelyek a városrehabilitáció transzferálhatóságához szükségesek.

A kötet legnagyobb terjedelmü fejezete a hazai városfelújítási tevékenység eddigi eredményeit mutatja be különböző aspektusból. Öt tanulmányból négy a fỏvárosi városrehabilitációs programok tapasztalatait ismerteti, egy pedig a lakásmobilitással kapcsolatos kérdéseket tárgyalja, vidéki nagyvárosi példákat is segítségül hívva.

Az elsỏ tanulmány szintén Egedy Tamás írása, amely a városrehabilitáció lakásés társadalmi mobilitásra gyakorolt hatásait, valamint a rehabilitáció várható társadalmi következményeit tárja fel. Elsőként az elméleti háttérrel és a kutatásba bevont mintaterületek jellemzőivel ismerkedhetünk meg, majd budapesti és vidéki nagyvárosi akcióterületeken végzett empirikus kutatás eredményeinek bemutatása, valamint a hozzá kapcsolódó statisztikai adatbázisok elemzése következnek.

Kovács Zoltán „A városrehabilitáció eredményei és korlátai Budapesten” címü írása arra fókuszál, hogy a fővárosban miként alakult a városrehabilitációs tevékenység az elmúlt évtizedben, valamint milyen tényezők hátráltatják a regeneráció folyamatát. Megismerhetjük, hogy a sajátos magyar mechanizmusoknak köszönhetően miért nem mủködnek a nyugat-európai városokban alkalmazott stratégiák. A tanulmányban a budapesti városrehabilitáció történeti áttekintése után a rendszerváltozást követő rehabilitációs programok, azok résztvevői és a projektek tapasztalatai kerülnek bemutatásra. A Szerzỏ a társadalmilag fenntartható városfejlődés és a városrehabilitáció korlátai között kiemeli azokat a politikai, lakáspiaci feltételeket, környezeti-városszerkezeti adottságokat, demográfiai trendeket, szegregációs viszonyokat és lakásmobilitási tényezőket, amelyek az elemzések alapján alapvetően hátráltató tényezőkként jelennek meg a városrehabilitációban.

A fenti tanulmányhoz szorosan kapcsolódik a fỏvárosi rehabilitációs programok és eredmények bemutatásával foglalkozó tanulmány, amely Egedy Tamás, Kovács Zoltán, Székely Gáborné és Szemző Hanna közös írása. A tanulmány négy budapesti mintaterületen - Középső-Ferencvárosban, Középső-Józsefvárosban, KőbányaVárosközpontban és Újpest-Városközpontban - végzett vizsgálatok segítségével foglalja össze a fővárosi városrehabilitáció pozitiv és negativ tapasztalatait, eredményeit, társadalmi hatásait, az együttmüködésben részt vevő szervek tevékenységeit, továbbá a rehabilitáció társadalmi fogadtatását és jövőbeni elképzeléseit.

A városrehabilitáció egyik sajátos eleme, a zöldterületek funkciója és szerepének fontossága kerül előtérbe Mikle Kinga Melinda tanulmányában. A tanulmány alapja egy döntően empirikus módszerekre épült kutatás, amely nemzetközi projekt keretében készült, és fő célja a városi zöldfelületek értékelése volt ökológiai, közgazdaságtani, szociológiai és tervezési szempontból. A vizsgálatsorozat öt európai nagyvárosban készültt, közöttük Budapesten is, ahol a fővárosiak parkhasználati szokásai kerültek a kutatás középpontjába. A tanulmány kiemeli a zöldterületek városrehabilitációban betöltött szerepének fontosságát, amely a Középső-Ferencvárosi mintaterület zöldterületi politikáján keresztül kerül bemutatásra. Mint azt a Szerzö 
Tér és Társadalom 20. évf. 2006/1. 147-163. p.

hangsúlyozza, a zöldterület-fejlesztés fontos eszköze a városrehabilitációnak, az életkörülmények javításának.

A fejezet utolsó, az építész-urbanista Locsmándi Gábor tanulmányában teljes körü történeti áttekintést olvashatunk a Ferencvárosban tervezett és megvalósított rehabilitációs folyamatról, a döntési mechanizmusokról, a rendszerváltozás elỏtt és után megjelent szereplőkről. A terület múltját és jelenét, a városrehabilitáció eredményeit kitűnő fotókkal illusztrálja a Szerző. A tanulmány rávilágít arra, hogy a társadalmi hatások és a lakásállomány minőségi változásai a ferencvárosi rehabilitáció kiemelkedő eredményeivé váltak, s új kihívásokat, új típusú társadalmi folyamatokat (dzsentrifikáció) indukáltak a területen.

A tanulmánykötetben önálló témakörként jelenik meg a lakótelepek rehabilitációja. A Szerkesztő írásában a magyarországi lakótelep-rehabilitáció helyzetéről, annak társadalmi megítéléséről, a paneles lakótelepek rehabilitációjának eddigi eredményeiről, valamint a lakótelep-felújitás legfontosabb lépéseiröl szerezhetünk információt. A lakótelep-rehabilitáció lépéseinek ismertetése során, szemléltető fotók segítségével, betekintést nyerünk a müszaki felújítások, átalakítások lehetőségeibe, eredményeibe, valamint ehhez kapcsolódóan megismerkedhetünk a társadalmi és gazdasági rehabilitáció jelentöségével, a lakótelepek társadalmi szerkezetének átalakulásának lehetöségével egyaránt.

Csizmady Adrienne munkája a lakótelepek átalakulásával, a paneles lakótelepek jövöjével foglalkozik, ami napjaink várospolitikájának egyik legaktuálisabb kérdésévé vált. A probléma központi kérdései között szerepel az, hogy a lakótelepek fizikai problémáinak megoldása önmagában nem elég, mivel a fizikai hiányosságok mellé gazdasági és társadalmi problémahalmaz is társul. A kutatás így a lakótelepek fizikai környezete mellett a társadalmi háttérre fókuszál, a problémát magyarországi és nyugat-európai (nyugat-berlini) területeken bemutatva. A tanulmány a történeti áttekintés szempontjait követve ismerteti a lakótelepi lakáskiutalások lefolyását, a lakótelepi lakásban élök összetételének változásait, az 1990 után végbement lakásprivatizáció hatásait, továbbá a lakótelepi rekonstrukció eddigi formáit, lehetőségeit és veszélyeit. A Szerző empirikus kutatásainak eredményei segítségével felvázolja egy lakóteleprehabilitációs terv kidolgozásának tényezőit és egy lehetséges sémáját, amelynek alapját a lakótelepeken élők társadalmi státuszcsoportjához történö illeszkedés adja.

A kötet utolsó fejezete - „Müemlékvédelem és városfelújitás címmel” - szintén önálló témakörként, a városfelújítás érdekes színfoltjaként jelenik meg. Új megvilágításba helyezi a városrehabilitációt, mivel a múemlékek felújítása éppen olyan jelentöséggel bír egy város imázsának, élhetőségének szempontjából, mint egy lakóház vagy zöldterület felújítása. Erö Zoltán tanulmányában arról olvashatunk, hogy mikor jelent meg a müemlékvédelem gondolata és ez területi szempontból Európa szerte milyen eredményeket hozott. A tanulmány legfontosabb témaköre a hazai müemlékvédelmi beavatkozásokat helyezi előtérbe és kíséri végig a gondolat 1960-as évekbeli megjelenésétöl, majd zárásként a nagyobb volumenú, budapesti mủemlék-felújítási projektekkel ismerkedhet meg az Olvasó. 
Jankó Ferenc "Történelmi városnegyedek sorsa - tapasztalatok és tanulságok Sopronban" címü tanulmányának célja a történelmi városokban, közöttük kiemelten a Sopronban zajló felújítási folyamat bemutatása. A vizsgált város esetén a Szerző saját empirikus kutatási eredményeinek segítségével prezentálja a mủemléki helyreállítások társadalmi-gazdasági hatásait, az eddigi felújítások tapasztalatait és ezek segítségével felvázolja a müemlék-felújítással kapcsolatos várospolitikai irányokat, azok lehetséges jövőjét is.

A könyv a formai követelményeknek megfelel, karakterkészlete jól olvasható és egészében esztétikus benyomást kelt az Olvasóban. Negatívumként említhető, hogy a fotók és illusztrációk minősége néhány esetben kifogásolható, illetve az illusztrációknál több esetben hiányzik a forrásmegjelölés. Emellett néhány adattábla szerkesztésébe hiba csúszott, $\mathrm{s}$ a diagramok esetében nem mindenhol szerepelnek a mértékegységek. Mindez azonban a tanulmánykötet élvezhetőségét és érthetőségét érdemben nem befolyásolja.

A recenziót készítő összegzö véleménye szerint a tanulmánykötet legnagyobb erénye a tudományos jellege, valamint a könnyen értelmezhetősége és gyakorlatorientáltsága is. A kötet szerkesztője és a szerzők fontos ismeretekkel gazdagították a földrajztudományt, a kapcsolódó egyéb társadalomtudományokat, és reményeink szerint hozzájárultak a városfelújítás tudományos megalapozásához is. Ezt a hozzájárulást talán a legjobban a kötetnek a következő gondolata jelzi: „A városrészek felújitása során nélkülözhetetlen egy átfogó szemléletmód alkalmazása, hiszen az eddigi tapasztalatok egyértelmüen bebizonyították, hogy az épületek és a lakókörnyezet kizárólag fizikai rehabilitációja önmagában nem garantálhatja a városrész sikeres felemelkedését, a terïlet gazdasági és társadalmi integrálására is nagy hangsúlyt kell fektetni." 